\title{
Fine Artists of Panay: A Pioneering Study of Their
}

\section{Works and Lives}

\author{
Lucell A. Larawan
}

Central Philippine University, Iloilo City, Philippines

\begin{abstract}
This paper documents the works and lives of selected visual artists from Panay provinces. The selection of the artist was based on meeting at least two of the following criteria: (1) The artist should have a major award(s) in any prestigious national fine arts contests which included the MADE (Metrobank Art and Design Excellence), AAP (Art Association of the Philippines), Petron, GSIS (Government Service Insurance System), and the Biennial Dumaguete Open Terra Cotta Festival contests; (2) He/she should have had one-man or two-man exhibitions at reputed galleries; and (3) He/she should be active in the local art scene, meaning, a continuous schedule of exhibits during the past three years. Mostly self-taught, the artists' artistic inclinations manifested early in childhood when they discovered their talents; this led to their resolve to seriously pursue with enduring fervor their art careers. Their sense of calling amid a less ideal art scene did not give way to the voice of conformity but they have maintained a clear sense of identity and destiny as inspiring art icons in their milieu. The analyses of the works of these artists lead to the observation of the Panayanon artistic tradition. Aside from the formalist descriptions of the artworks' features, the analyses go further into the contextual and evaluative levels that reveal a highly nuanced meaning and semantic richness of the works. The paintings and sculptural pieces of the artists are expressions of their true “voices”, fresh innovations that have earned accolades even if these innovations are untamed by the academe.
\end{abstract}

Keywords: fine artists, Panay, artistic tradition

\section{Background}

The National Commission for Culture and the Arts records a brief history of Philippine art, briefly highlighting the luminaries of the field. The classical tradition in Philippine painting had its roots in the first painter of note, Fabian de la Rosa (1869-1937). Later, there was De la Rosa's nephew, Fernando Amorsolo y Cueto (1892-1972), who became the first national artist. The works of these artists were literal landscapes.

Modernism in Philippine painting started with the distorted and naked working men of Victoriano Edades (1896-1985). Edades recruited two young dropouts from the UP (University of the Philippines), College of Fine Arts, Carlos “Botong” Francisco, and Galo Ocampo. The Triumvirate of Edades, Ocampo, and Francisco became the core of a group of artists informally known as the Thirteen Moderns. The other Moderns (according to Edades’ list) were Diosdado Lorenzo, Vicente S. Manansala, Hernando R. Ocampo, Cesar T. Legaspi, Demetrio

Lucell A. Larawan, member of the National Commission for Culture and the Arts-National Committee on Visual Arts and recipient of the Commission's competitive research grant, associate professor at the College of Business and Accountancy, Central Philippine University. 
Diego, UST (University of Santo Tomas) faculty members Bonifacio Cristobal (1911) and architect Jose Pardo (1916), Arsenio Capili (1914-1945) who died during the Japanese war, two student-assistants-Ricarte Purugganan (1912-1998), and Anita Magsaysay-Ho (1914), the only woman in the group. Other names which gained significance were Fernando Zobel (1924-1984), Nena Saguil (1914-1994), and Jose Joya (1931-1995). The year 1995 was an eventful year for Philippine visual arts. The AAP (Art Association of the Philippines) Semi-annual Competition and Exhibition at the Northern Motors Showroom was marred by "The Walkout" of conservative artists. After the opening of the exhibition, they took their entries and put up their own exhibition across the street. It was their sign of protest for what they perceived as a bias for Modernist works in the awarding of the Rotary Club’s Golden Anniversary Awards, all of which went to Modernists Galo B. Ocampo, Manuel Rodriguez Sr., and Vicente Manansala. In 1959, the AAP decided to stop its practice of awarding two categories, perhaps realizing that there was just one standard for judging art, not two.

In the sixties and seventies, several young artists were on the rise such as Bencab, Antonio Austria, Manuel “Boy” Rodriguez Jr., Roberto Chabet, Norma Belleza, Jaime de Guzman, Danilo Dalena, Imelda Cajipe-Endaya, Justin Nuyda, and Angelito Antonio among others. This new generation ensured that Modernism, in particular, and Philippine painting, in general, remain alive and well into the next decades (Retrieved from http:www.ncca.gov.ph).

Panay is endowed with acclaimed talents in the visual arts. Despite this reality, the region is facing a dismal art scene due to the overall negative art appreciation and development culture manifested by the lack of researches that document the works and lives of its fine artists. Defensor (1992) in an M.A. thesis wrote about the works of the deceased local artist Vicente San Miguel. The rest of the writings available are scant essays and reviews that cannot yet establish a significant pool of knowledge on the fine arts of Panay.

\section{Artists of Panay}

\section{Edmar Colmo: Vanguard Social Realist}

Edmar Colmo (1980- ), a resident of Molo, Iloilo City, was the Philippine representative to the Beijing Olympics Sport and Art Contest in 2008 where his entry in painting was named Highly Recommended. He started as a finalist in the Shell National Student Art sculpture competition (1999). Later, he successively earned three semi-finalist distinctions from Metrobank Young Painters National Competition and Metrobank Art and Design Excellence. His entry in the Philippine Art Awards was one of the 10 winners in the Visayas and became a finalist in the national awarding. Colmo has joined a number of group exhibits in Cebu, Bacolod, and Iloilo.

Critique of works. With works that challenge the beautiful side of life, Colmo understands his role as an artist. An artist who lives in a degenerate time should mock, satirize, and document the decay in society. In a period of harsh realities abound in the social milieu, one cannot just choose any course. Life is circumscribed by these realities and no amount of romanticism will alter it.

A protest artist, Colmo concerns himself with provoking and engaging the attention of the masses. His paintings express the Filipino’s or even the global citizens’ problems and their times.

Using dominant linear elements rendered in pen and ink or acrylic, the artist usually draws or paints distorted faces and human figures which provoke insights on political, social, and personal experiences. The content of his art is typically shocking and subversive. His messages have the goal of becoming agents of change. 
As protest art reflects a current societal ill, it can be an agent of change.

Colmo is a vanguard of a style which possess a different hallmark that led to his selection to the Philippine Art Olympics. Few artists create a unique presentation and many are mostly followers or protégées of art schools.

Ako, which presents a famished woman, is a stark reminder of oppression set beside society's negligence, a characteristic of the marginalized sector. The subject is wearing a Muslim attire and the symbolism of the crescent moon denotes a subculture in southern Philippines. Another symbolism is the nail-pierced hand —an allusion to the crucifixion - where the message of suffering is presented. The anguish of the enraged face and the use of red for the color of the skin add to the artwork's purpose which is to awaken society from its apathy towards certain sectors. The biomorphic forms on the ground are surrealist presentations that suggests the birth of more repulsive creatures.

Colmo overcame the reactions of those whose beliefs or notions are challenged by his counter-paradigmatic art. Although not everyone likes his artistic expressions, somehow his strong resolve to express his true voice earned him the high regard among the members of the art community.

\section{Gary Custodio: Painting Echoes of Visual Music}

Gary Custodio (1968- ) is a Bachelor of Fine Arts graduate of the University of Santo Tomas where he graduated in 1992. He lives at Andagao Beach, Kalibo, Aklan although he occasionally stays at his brother's place in Baclaran, Parañaque City. He has earned numerous awards in national art contests and had a one-man exhibit in West Gallery, Quezon City. From the Metrobank-sponsored contests, he was awarded three second prizes and one third prize. He became a two-time finalist in the Philippine Art Awards and also a finalist in the GSIS (Government Service Insurnce System) painting competition. He started as a graphic artist at Philweb, Makati City from 2000 to 2003. Later, he worked as a product designer of Passad Export and Obras, Co. in Iloilo City until 2006. At present, Custodio is a full-time artist whose passion in the visual arts has found a better milieu.

Critique of works. The transience of human construction and man's relationship with his environment have a great impact in Custodio's body of works. His art shows how the natural world has played an important role in the story of mankind by man's continuous intrinsic link with the environment. The modern world, however, leaves little room for the contemplation of nature and the cultivation of a relationship with one's environment. The notion of an unspoiled terrain has become something of a Holy Grail, the longing for many especially Custodio.

Custodio draws upon the precarious relationship between man and the man-made environment. His paintings resemble architectural models but rather than celebrate man's triumph over the natural world, they exhibit unease about man-made structures-physical or organizational. They draw attention to how people cling to the environment they have created and how easily they have forgotten the power of nature. The physical structures built by modern architecture and engineering represent the epitome of man's taming of the natural world. In building skyscrapers, the ramifications of such endeavor must not be brushed aside, as Custodio infers in his paintings. The organizational structures built as mechanisms in running corporations have permeated the business world. They can mean efficiency, effectiveness, and economy in meeting business goals; however, they also suppress the individuality and humanity of man. The artworks bring to the viewer the artist's consciousness, leading to man's exercise of more responsibility in dealing with the environment through the seen and the unseen structures.

Custodio's works also reveal a profound theological insight into the temporal nature of man's existence and 
man's innate longing for the enduring celestial city. This insight was shown in the title of Custodio's latest solo exhibit which was "Impermanence". The paintings do not show a symbol for that object of longing but they are eloquent as man may not always be aware of what he really needs amid the challenge of impermanence.

During the Metrobank Young Painter’s Annual of 1999, Cid Reyes said of Custodio’s work which won 2nd place:

Abstraction, as a visual language, demands of the viewer a measure of surrender to its ambiguity. The absence of a figurative image (which the eye immediately attempts to seize), while it may at first confound the viewer, intentionally heightens the interplay of the plastic elements: line, color, tone, shape and perceptions thereof. In Gary Custodio's Unknown, these elements seem to merge and vanish, only to surface as an illumination of feeling, and evocation of space. If the viewer so wishes, he can perceive, lurking from this evanescent image, certain intimations of cityscape and the slippage of a human form. But these luminosities of reality are, indeed, merely the expressive echoes of a visual music. (Reyes, 1999)

\section{Angelo “Jun-jun” Duarte: Prince of Mixed Media}

Angelo "Jun" Duarte (1967- ) tried related professions and made distinctions in each of them. As a visual artist, he is a second prize winner (mixed media) and honorable mention (painting) in the competition of Art Association of the Philippines (2003) and finalist in the Philippine Art Awards (1999). He was featured in radio and in ABS-CBN Iloilo. He has held three solo exhibits and a number of group shows in Iloilo City. He founded the Baysulangpu Society and Kurit Ilonggo Artists groups. With his achievements, Duarte became a nominee to the CCP (Cultural Center of the Philippines) 13 Artists Award.

Critique of works. Like the emperor's new clothes, the content and motive behind much of modern art warrant close scrutiny. This is especially true in a style which considers the idea more important than the finished product. The painting either markedly de-emphasizes or entirely eliminates a perceptual encounter with unique objects in favor of an engagement with ideas.

The conceptual art's chief synonym is idea art. The idea, rather than the object, is paramount. To circumvent the too-narrow limits of art, Duarte uses aspects of semiotics and popular culture to create works that barely resemble traditional art objects. What the viewer sees is simply a document of the artist's thinking.

Antecedents of concept art are commonly regarded as aesthetic activities. At a deeper level, interesting concepts, concepts enjoyable in themselves, especially as they occur in mathematics, are commonly said to "have beauty".

Duarte's mixed media art is mostly negotiations of the common: detritus reemployed to communicate repeatedly ideas concerning our use of and respect for resources and their source.

The artist's intention and form employ, perhaps cohere around, structured fluidity. The square or rectangle that contains the wall-mounted objects beautifully merges with the fluidic composition that creates visual music.

There is a disarming honesty in Duarte's words and works. He has demonstrated conceptual strength and creativity — a marked ability to use the mundane imaginatively to make the viewer take a second glance at the traits he is critiquing. The low-status materials confront and invite new views, which in fact build upon previous experience.

In Paraw Regatta (see Figure 1) and Conjecture, the dominant linear elements combine to produce rhythm. Paraw Regatta is inspired by the yearly Festival in Iloilo City. Boats with painted sails compete. Painted hand-made 
paper and strings resemble the waves of the sea. The two vertical straight strings in yellow balance the nuances of curved horizontal lines. The composition is enriched with splattered blue paint situated randomly in the area with no fixtures. On the other hand, Conjecture is a white monochrome of lines accented with small red dots. Unlike Paraw Regatta, the curve lines that dominate are vertically positioned while two big lines combine horizontally. The vertical lines seem to represent energy flowing from a source which shows a metaphor of the concept. From such energy, many great inventions flourish. Many of them start with wild guesses, not structured thinking.

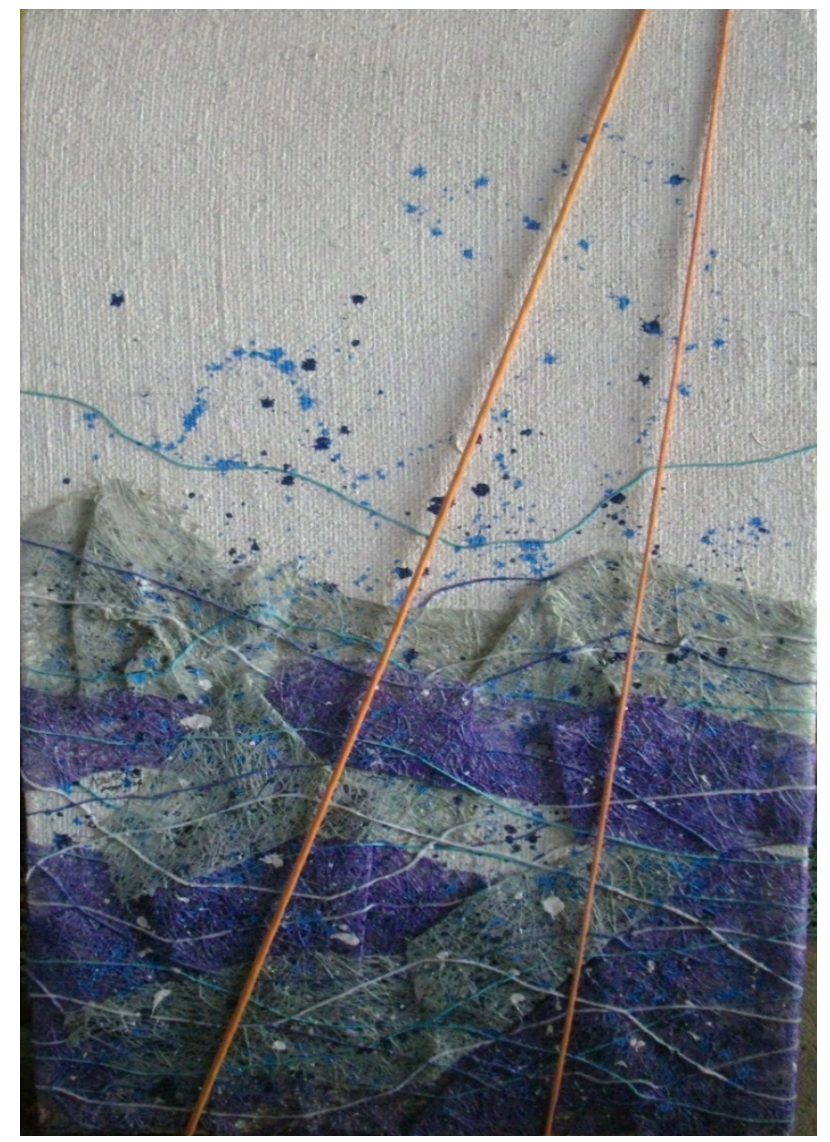

Figure 1. Paraw Regatta, mixed media, 2 ft x 4 ft, by Angelo “Jun” Duarte.

Indigenous materials in burnt umber form loose lines in a sporadic array in Duarte's Fireworks. An object shaped as an irregular triangle appears in the left portion of the board. To give attention to the object, a dry brush of blue is applied around the object to separate the surrounding space. The painting shows that some fireworks producers thrive in Iloilo to provide the supply during Christmas and the new year. Although at the figurative level, Fireworks revolves around the short-lived span of human technology where after consumption, they are nothing but rubbish.

Duarte's works reflect the artist as a Catholic-animist. As an animist, he gives tribute to the sacredness of nature.

\section{Jose “Joe” Dureza: Leader of Artist-Voyagers}

The development-conscious institutions in Panay should think of establishing a system of awarding those who carry the banner of the region's honor and pride in the arts. Truly deserving of the distinction is Jose "Joe" Dureza (1941- ), one of the leading lights of the visual arts. Born in Roxas City, Dureza first worked in Bacolod 
City, then later migrated to New Jersey. In New Jersey, he co-founded and presided (for 10 years) over the SPAA (Society of Philippine American Artists) together with Manuel Rodriguez, the foremost printmaker of the country. He earned feathers on his cap as first prize winner in graphics, being a Liquitex Awardee and Artist of the Year of Hudson Artists, Inc., and Best of the Show Awardee of SPAA (Society of Philippine-American Artists). His assignments and scholarship grants from Fulbright and Rotary took him to the US, France, and Yemen.

Critique of works. Art reflects reality. Art is humanity's attempt to recreate reality, to create reflections of reality—and imagination and creativity are part of reality. Aesthetics, as emphasized in Dureza's vision creates identity or set of enduring concepts that can be linked to certain traditions or art movements.

Dureza's experiences as a transplanted Filipino in Secaucus, New Jersey shaped and transformed his art. He wrote:

Each art work is as unique as its creator. We, however, like a piece of art for many reasons, often very personal ones; sometimes it is about the subject, sometimes it is about the artist and how that artist sees the subject through his or her eyes. My paintings are a personal view of our world presented in a manner that people have not seen before and therefore every time I present a painting, I am inviting others to look into my soul. (personal communication, 2010)

Landscape painting is a distinct genre of painting which captures nature in its elemental form. It is a reflection of the skies, seas, rivers, the sun, the moon, and greeneries. Dureza, poet of the land and sea, reveals the artist's reverence for peace, beauty, solitude, and solace he finds in natural grandeur wherever he goes.

While occasionally painting persons, Dureza—as a romanticist—takes a look very minutely to the factors like the struggle the person has faced and the mood he/she is generally occupied. These qualities are in the portraits commissioned in the US. In Death March and Japanese War, he has applied the principle used in his portraits.

Using ingenuity to portray garden flowers in watercolor, Dureza did Spring Bouquet. The vibrant red, blue, yellow, and white are a celebration of life at its fullest. The exuberance of the composition is reminiscent of Dureza's productive art career in the US. Hope and life in the bouquet painting inspires the following Hiligaynon poem by the researcher: Sang nakita naton ang ginpinta nga mga bulak/nagpati kita liwat sang paglaum—iisa ka korus ginkanta sa mga duag:.../nagpati kita liwat sang pagkahingpit-/dihon nga gin umpisahan sang bag-o nga tinuga/namukadkad sa aton pagkatawo ("When we saw the floral painting/we believed again in hope—-a chorus sang by the colors.../we believed again in perfection—/form that began in a new creation/blossoming in our being”).

Dureza has painted for more than 50 years. His body of works documents his journey from the Philippines to New Jersey, reflecting his passion and sentiments for his native land as well as for America.

\section{Martin Genodepa: Transforming Stoic Stone}

Martin Genodepa (1963- ) is a self-taught specialist in stone sculpture. His favorite media are coral stones and sandstones which are abundant in the environs of Guimbal, Iloilo where he resides and has set up his studio. He has had nine solo exhibitions in Iloilo, Manila, the US since 1992: at the UP Visayas Art Gallery, Museo, Iloilo, Tangahalan Fernando Amorsolo of the Cultural Center of the Philippines, the Hiraya Gallery, and the Vermont Studio Center's Red Mill Gallery. In 1999, he was a recipient of the Freeman Fellowship for Asian Artists, full grant awarded by the Vermont Studio Center. He was an artist-in-residence in the art colony. He appeared in Travel Time's New Kids on the Art Block television documentary together with Alfredo Esquillo, Marcel Antonio, Gabriel Barredo, and Dansoy Coquilla. Genodepa has gotten favorable reviews from respected 
Filipino critics like Alice Guillermo and Eric Torres and has been featured in art publications. Genodepa's themes vary from grace under pressure, alienation and isolation, and feminism and sexuality to human and societal disintegration.

Critique of works. Raised in a serene and close-to-nature environment in Guimbal, Sculptor Martin Genodepa derived his spirituality and creative energy from an alchemy of nature and awakened consciousness. His sculptural works reject theatricality and detail in favor of radical simplification and abbreviation. His goal is to capture the emotion of human beings rather than tell a story—and render this emotion visible with minimal formal means. Mostly, his sculptural works are coral stone although he also sculpts sandstone or marble.

Coral stone is a rare medium and Genodepa finds joy in forming his usual subjects—women. He does not scuba-dive the nearby sea to get the material for that would mean a conservationist's nightmare. He only combs the beaches to find coral large enough to be fashioned into sculpture. For him, art should be ecologically-friendly.

Woman as the subject of his works is first of all a symbol of fertility. From her, springs forth life and a child's earliest experiences of nurture and care. She is more capable of showing a simple emotion. But in Genodepa's works, she is no stereotype of the elusive women of myth. These women do not belong to the folk inhabitants engaged in day-to-day activities.

Genodepa's minimalist approach which focus on human heads evokes a dominantly hilarious and romantic emotion. The shapes and textures create harmony and rhythm which contribute to the noteworthy quality of the artworks.

The viewer does not miss the stark irony—fragile human beings shaped from stoic, hard, and passionless stone. This is both to protest and battle alienation and lack of privacy which are the usual effects of modernization. The stone made soft by tender expressions depicts the struggle to maintain one's dignity and self-awareness in the midst of a more impersonal and busy society which is alluded by a cold and formless piece of stone. If humanity in the 21st century continues to stifle man's innate emotions for the sake of efficiency, truly the stones will start crying.

Genodepa often depicts the head with the bust as a unitary irregular circle or ovals. Evoking images of repose like Brancusi's works, Genodepa's heads are usually positioned to convey an ecstatic mood with faces rendered in a cubist manner. The women in coral stone are subtle monuments to the aesthetic act and to the fact that women are its inspiration.

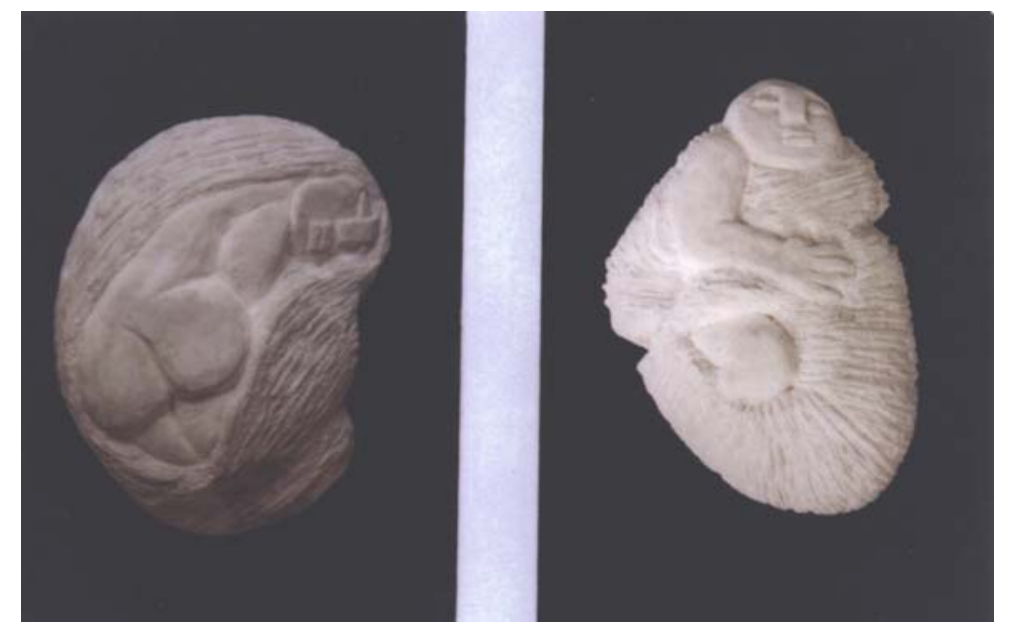

Figure 2. Wrapped Series 2003 \& 2004, coral stone, 10” x 9” x 4”, by Martin Genodepa. 
Wrapped Series (see Figure 2) shows the woman's head in an inclined position almost blanketed with her long hair. Part of the back and hips are visible. The message it seems to communicate is the typical conservative woman who preserves her dignity and respect.

The appeal of Genodepa's works lies in his instinctive understanding and appreciation of his material, coupled with an unfailing sense of design through which he is able to make full, expressive use of the coral medium. With these figures he brings into sculptural realization hitherto submerged passions, impulses and feelings even as the coral stones had been dredged by the tides from the bottom of the sea to the open shore. (Guillermo, 1999, p. 7)

\section{Edgar Gonzales: Culture Painter With a Style}

Edgar Gonzales (1948- ) is one of the oldest painters in Iloilo. As a "father" to some artists, he trained some who later became productive local artists. Gonzales had made two solo exhibits at UP Visayas Art Gallery (1983) and at Museo Iloilo (1984), while he participated in a number of group shows. He has a number of awards which include the International Art award in a children's art competition (1965), 2nd prize in regional painting contest (1980) and President Marcos trophy in the National Health Poster contest (1984). His art profession has been a major source of his family sustenance. The owner of an establishment in Iloilo awarded his three children full scholarship in high school and college in exchange of his art services. Having earned a reputation in the local art scene, he has been tapped as one of the judges in the Dinagyang Festival.

Critique of works. Art reflects the truth of the cultural milieu as Edgar Gonzales's works emphasize. The artist creates in a historical moment and art reflects that reality, that historical moment.

George Scharf, friend of George Eliot's and an important figure in the Victorian art world, once contrasted "the historical, heroic, or idealised style of figure-painting" with genre painting, which he defined as the "representation of life in its unheroic forms". Gonzales has used both types. Aside from narrating important historical events in Panay, he has also glorified the ordinariness of rural life activities.

Gonzales distinguishes himself by using a medium he is famous for-pen and ink on board or vinyl. When he uses the medium, he combines it with wash watercolor to achieve more than a monochromatic effect in the composition.

Barter of Panay in acrylic is based on a folk account which is commemorated by a festival in Kalibo. The scene on the beach tells of the forging of ties between the Ati and the Bornean visitors. The group at the left is the Ati dwellers who welcomed the ten Bornean datus. Researches revealed that the incident happened in 1212 when 10 Bornean datus, led by Datu Puti and their subjects, escaped the tyranny of Sultan Makatunaw by boarding the baeangays to seek peace in a new place. They found it in Aninipay (Island of Panay) which the datus named as the Island of Madyaas ("Paradise") in contrast to the island where they came from.

Carabao Race, a drawing, presents the yearly festival in Pavia, Iloilo. The cross-hatching method in using the pen and ink expressively highlights four carabaos with their riders. The body movements of running are seen among the beasts of burden. Carabaos in the drawing is an embodiment of the Visayan rural life, wholly representing the culture of the farmer's level of modernization, industry, love of nature, and kindness to animals (Funtecha, 1995).

The carabao, the artworks's inspiration, is considered to be the beast of burden but sometimes it is the source of recreation through the annual carabao-carroza race held every May 3 which is the town fiesta of Pavia.

Old Iloilo (see Figure 3) drawing poses a sense of sentimentalism for what Iloilo City, particularly Calle 
Real, used to be with old cars and calesas. The place is known for its ancestral buildings, some of which are preserved to evoke nostalgia. In the absence of old pictures to show what the place used to be, the drawing narrates the rich history of the city.

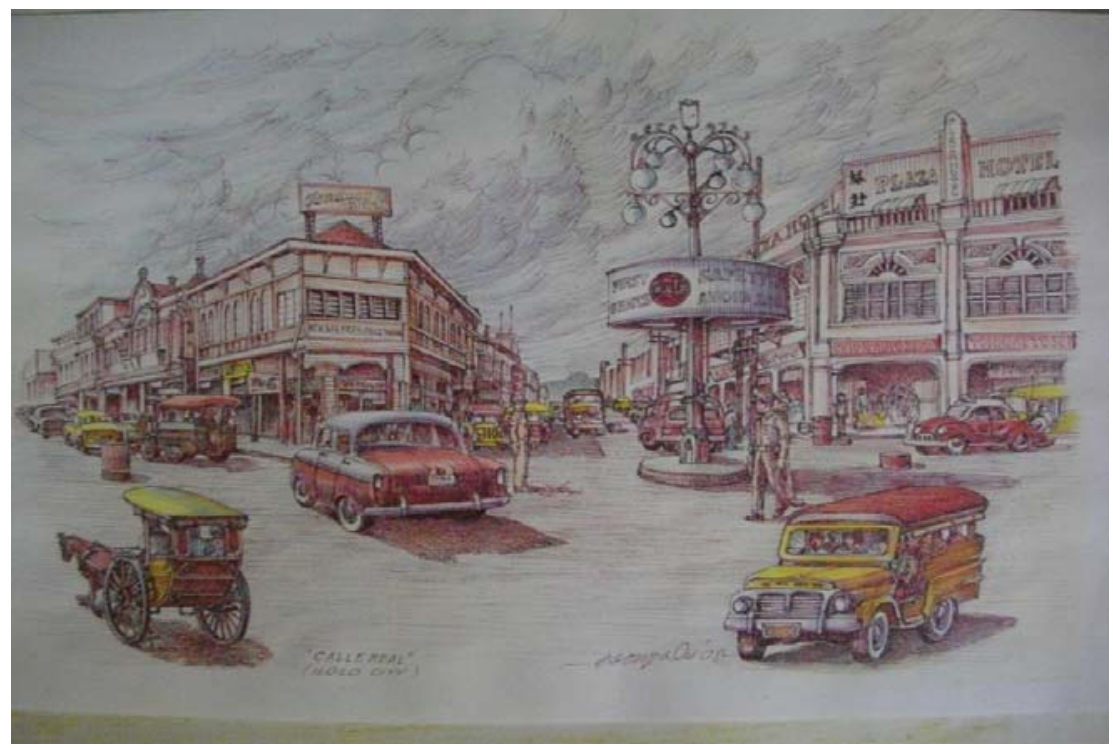

Figure 3. Old Iloilo, ink on vinyl, 30” x 40”, by Gonzales.

Folk imagery (from the German volk, meaning people) has been the talismanic source of the artist's excellent oeuvres.

\section{Allain Hablo: Call to Meditation}

Allain Hablo (1968- ), from Estancia, Iloilo, is one of the select self-taught artists specializing in abstract minimalism. He has been a recipient of the 9th Annual Freeman Foundation Vermont Studio Center Award. He availed himself of this artist-in-residence grant in the US in 2001-2002. Through the grant, he presented his first solo exhibit at Red Mill Gallery, Johnson, Vermont. His second solo came six years later at Avellana Art Gallery, Pasay City. Hablo has a number of awards in visual arts. Highest among them is the second prize in sculpture (open art competition) from the AAP, 2004. From AAP, he also got a juror's choice (1993) and four honorable mention (2001, 2002, and 2003) awards. In the Philippine Art Awards, Hablo was a juror's choice awardee (2005) and a four-time finalist (2000, 2001, 2003, and 2006). When still a young artist, he won third prize in Metrobank Young Painters Annual (2000) and got a finalist award in Shell National Students Art competition (1991). Hablo has judged during the Dinagyang Festival (2004) and served as a resource person in the Iloilo Visual Artists Association Art Forum.

Critique of works. From the contemplative nature of Hablo's oeuvre springs poetry whose elements are handled with careful purpose. There is nothing coincidental in the execution of his art, except the stark presence of the artist. The tension and nuances in the optimum content derived from a modicum of form are hallmarks of Hablo's works. These give them the distinction of creating literary pieces embodied in visual form.

Hablo philosophizes: "I believe art has to come from the intuitive nature of the subconscious. It should not, in one form or another, represent anything recognizable. It has to go beyond the limitations of the human senses, independent from reason for it to become universal” (personnal communication, May, 2010). 
Hablo's works invites the viewer to realize that even the simplest of human concepts are paradoxically complex. Meditation, the usual message of Hablo's works, cultivates states of mind that are conducive to peace and well-being and eradicate those that are not. The premise is examination of life. This leads to the discovery that most of man's time and energy is devoted to mundane activities, such as seeking material and emotional security, enjoying sensory pleasures, or establishing a good reputation. Although these things can make man happy for a short time, they are not able to provide the deep lasting contentment that he longs for. Sooner or later, his happiness turns into dissatisfaction, and he finds himself engaged in the pursuit of more worldly pleasures. Directly or indirectly, worldly pleasures cause his mental and physical suffering by stimulating attachment, jealousy, and frustration. Moreover, seeking to fulfill his own desires often brings him into conflict with others. Meditation shifts the awareness from the usual focused and outer-directed activity of the mind. It gives one an opportunity to shift gears, let go of this focus and experience a more peaceful and silent state.

In current times, the term meditation, which is the emphasis of Hablo's paintings, is used much more broadly to refer to many different practices meant to bring about a variety of results. Meditation is no longer always associated with spirituality. Different meditations have different goals, and people meditate for many different reasons - relaxation, health, personal growth, and spiritual development. Often people meditate simply to become more relaxed, or because their doctor has advised them to meditate to lower their blood pressure. Being clear on why one want to meditate will help him in his search.

The titles of Hablo's artworks in relation to the presentation of a few rectangles or squares and some lines are intriguing. There is no subject visible to support the idea of the artworks. Obviously, the artist's idea, not the object, is paramount in each artwork. The goal of such art is to react against formal and more commercial works of romanticists and realists, calling to a deeper reflection that goes beyond commercialism and towards deeper meanings of existence.

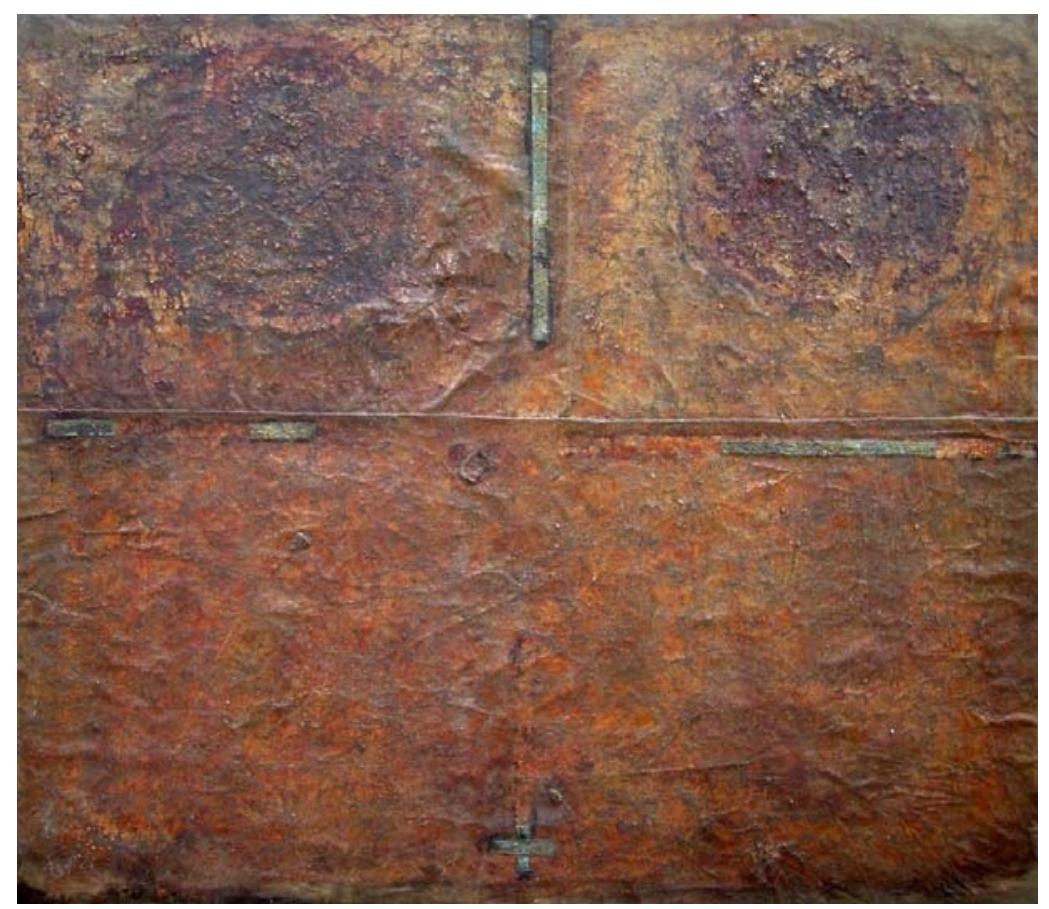

Figure 4. Faded Insights, mixed media, 45” x 52”, by Allain Hablo. 
Faded Insights (see Figure 4) makes one aware of the artist building up his imagery to speak to his contemplative and reflective nature. The mixed media painting is composed of intriguing textures all throughout the canvas. A few broken lines in light green form an irregular cross-like pattern. These lines complement the overall color scheme of the composition. Two loose circular shapes appear on the upper portion.

Dominantly black with few traces of burnt umber describes False Negative. Unlike Faded Insights, yellow lines appear on the sides and at the center. These lines form in pairs and meet at the center. In the middle, a loose darker line emerges to add some variety.

\section{Alex Ordoyo: Watercolorist of Ilonggo Culture}

Alex Ordoyo (1984- ) surprised his peers when he won the grand prize in the 8th Art Petron National Art Competition (Water Media Category) in 2008. In the national On-the-Spot National Poster Making Competition sponsored by the Ombudsman-European Commission, he also emerged as grand prize winner. During the 9th Art Petron National Art Competition, he was 1st runner-up in water media category and semi-finalist in the oil category. Ordoyo has had a number of group exhibits in Manila and Iloilo City. Because of his extraordinary achievements, Ordoyo is a Pasidungog awardee in the field of culture and arts in his hometown, Sta. Barbara, Iloilo.

Critique of works. Ordoyo's paintings are mostly in watercolor, the medium which he has excelled as a national champion in Art Petron and most of his award-winning entries. The medium is made of pigment ground in gum, usually gum arabic, and applied with brush and water on a painting surface, usually paper. Watercolor compares in range and variety with any other painting method. Transparent watercolor allows for a freshness and luminosity in its washes and deft calligraphic brushwork that makes it a most alluring medium. There is one basic difference between transparent watercolor and all other heavy painting media—its transparency. The oil painter can paint one opaque color over another until he has achieved his desired result. The whites are created with opaque white. The watercolorist's approach is the opposite. In essence, instead of building up he leaves out spaces. The white paper that is left out creates the whites. The darkest accents may be placed on the paper as the pigment comes out of the tube or with very little water mixed with the pigment. Otherwise the colors are diluted with water. The more water in the wash, the more the paper affects the colors.

To the artist, art mirrors society. Ordoyo's subjects focus on festivals, churches, and the plight of the poor and the oppressed. He also focuses on genre paintings that present the joyous: Pasungay Festival, Bagsakan, and Molo Church. Or in few cases, his paintings show unhappiness like the Depression.

Ordoyo limns churches, like the Molo Church, to celebrate Iloilo as a place known for historical churches. The churches which Ordoyo usually get inspiration are referred to by Jose Moreno (Spanish critic) as tequitqui, an Aztec term which means "tribute payer".

Also depicting social realities, Ordoyo protests the aftermath of urbanization and modernization. An artist who lives in a degenerate time satirizes or documents the decay. An artist should see his role in the stripping off of the mask of the fantasy of society's self-aggrandizement. Ordoyo hints this role in some of his paintings such as Compressor and Depression.

Compressor speaks of both deprivation and survival. The elderly woman begging, an eye clouded over with cataracs, asks for alms from passers-by. With a hideous look that is part-pleading and part-cursing, the horrifying visage of the woman must have of a proud human being forced to become an outcast by society's apathy. It 
speaks of humanity's descent as society fantasizes on self-aggrandizement. Though the current administration of Iloilo City disallows the presence of beggars on the sidewalks, beggars are still roaming around. An alternative social program could have been designed besides the effort to "cleanse" the streets to get rid of beggars.

Ordoyo, at age 25, creates art at a historical moment. Through his creations, he projects to the community an awareness of the current milieu. Having excelled in the watercolor medium, Ordoyo makes his presence secure in the Panay art world.

\section{PG "Boyet” Zoluaga: Seer of the 21st Century}

PG "Boyet” Zoluaga (1958- ) distinguished himself by winning local and national awards in the visual arts. He was the best entry in the Centennial Painting Competition of the AAP (1998), and juror's choice (1998) and finalist (1998, 1999, and 2000) in the Philippine Art Awards. Locally, he won first place (1998-1999) in the Pinta Paraw during the Paraw Regatta Festival, became champion (1993-1998) in the costume design of the Dinagyang Festival and got the 3rd place (2000) in the Pinta Lawas in the Paraw Regatta Festival. He served as faculty of the Special High School for the Arts at Iloilo National High School (1993-1998) and chairman of the Visual Arts Committee of the Arts Council of Iloilo Foundation, Inc. (1991-1993).

Critique of the works. The darker side of life expressed in bold lines and overall composition that emote fear, loneliness, hopelessness, and concepts such as phobia, isolation, and death are symbolized in the works of PG Zoluaga. With emphasis on environmental destruction and alienation, these are intended to portray the artist's deep sentiment for his community that suffer the plight of a third world setting and the harsh realities of modernization where exploitation, corruption, and dehumanization abounds. Using a social realist style, the influences of Munch and Chagall are evident in the works which effectively convey the intended message.

Zoluaga's deepest sentiment in the visual medium was popularized in the 1990's through his original song composition Iloilo Banwang Pinalangga (Iloilo My Beloved Town). The place is duog sang mga damgo (a haven of dreams) which captures one's affection. At the end of the song, Zoluaga makes a plea for his town, San-o mo ako mabatian? ("When will you hear me?”). Such plea is seen in his social realist paintings and drawings reflecting his protest to stop the "acts of men” which either destroy the environment or take people’s dignity and rights.

The theme of his color etching, Deliverance, is exorcism. The scene is a tribal dance with a shaman, the main subject, who performs a ritual to cast out evil spirits. The background using textural elements is a representation of the natural habitat in the rural scene with colors rendered in an almost monotonous range of black, sepia, and green. In a natural environment where the ritual is performed, it suggests of the presence of evil that needs to be dealt with using supernatural means. The work reminds the viewer of people's desire for an unknown power beyond which, in the Filipino culture, is summoned to counter the horror or demonization. Horror or demonic activities are alluded here as the social ills that need to be "exorcised".

Deliver Us From Extinction (see Figure 5) effectively communicates humanity’s struggle for survival. Linear elements in bamboo and fire dominate the composition that shows a horrific doom. Two people in the center personalize the bamboo poles which are abundant in the community. In the background are faces of human beings floating in a lake of fire and burning bamboo that gradually turns into ashes. The entire mixed media painting is a prophetic message that warns us about an impending doom both at the natural and spiritual levels. In the natural plane, it may be disasters that follow deforestation. In the spiritual plane, it suggests the "second 
death” which is possible for the deserving. More than suggesting destruction of natural environment due to kaingin (burning of trees), the painting eloquently emphasizes that people considered to be most important in the entire creation are actually the endangered species.

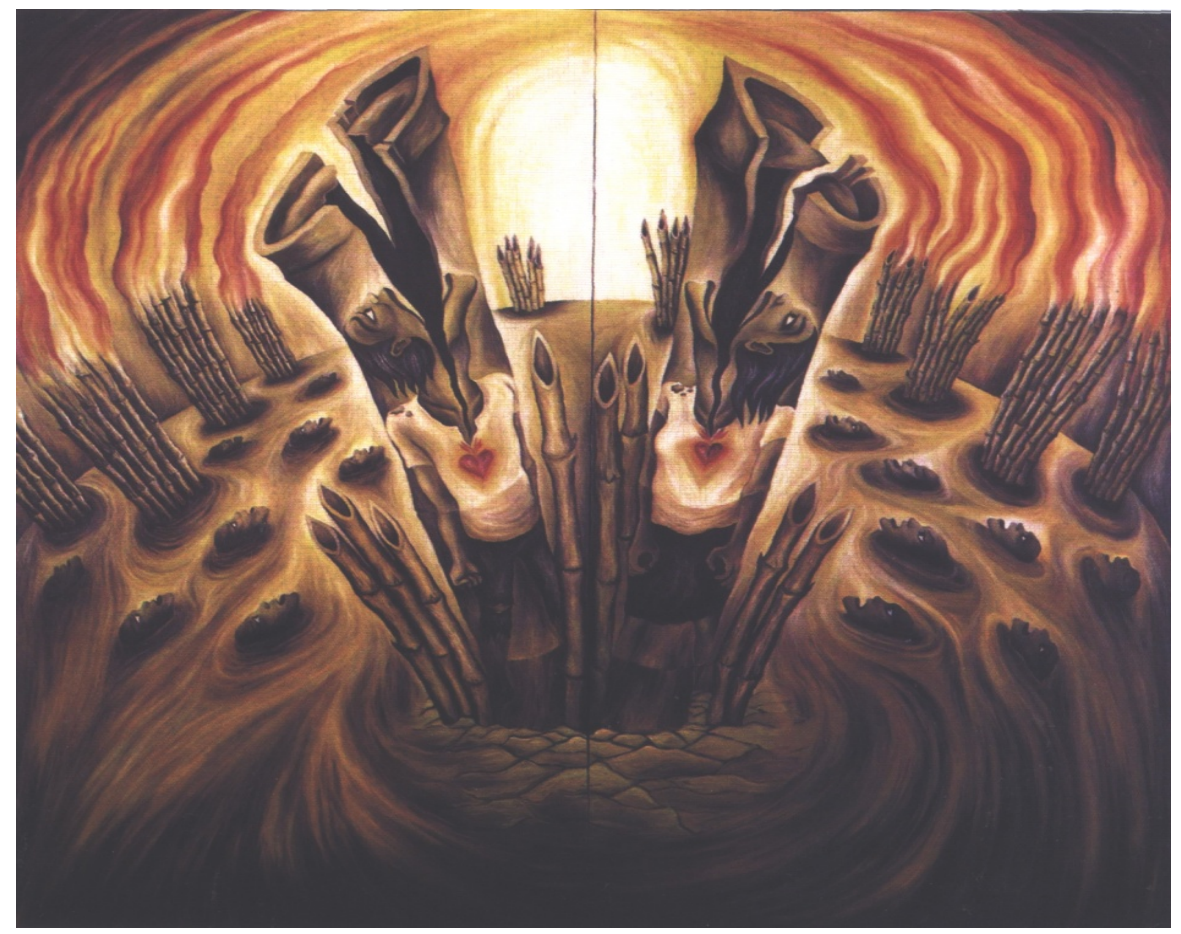

Figure 5. Deliver Us From Extinction, acrylic, $4 \mathrm{ft}$ x 4 ft, by Zoluaga.

Zoluaga’s sentiments are limned in the words of Filipino poet Edgar Maranan whose lament emotes:

In the beginning was the valley/of the river, slope of vineyard,/mills of driving winds, the lily/of the fields, dollhouses basking/through the golden seasons of the sun.../the end is blast of ancient rage,/all colors die, love ends, no child/cries out. There's only the rush of/gutted fleeing souls. (Don Carlos Palanca Memorial Awards for Literature, 2000, p. 206)

Zoluaga’s paintings are exquisite media expressing the sentiments.

\section{Discussion}

Panayanon society is a pluralistic society in transition. As such, Panay art which reflects its culture and sentiments, mirrors such characteristic. In Fred Rigg's (Retrieved from http://www2.hawaii.edu/ fredr/mccurdy.htm) explanation, such condition in a community is better understood using the prismatic model. The theory, based on the principle of light, asserts an insightful analogy: light as it arrives from a source like the sun is fused. All of the visible wave lengths are present, but they are combined into the single color white. Once separated, the individual colors appear as in the hues of a rainbow. One way by which light can be refracted into its separate colors is to use a prism. To Riggs, the white light represented the fused structures of a traditional society. The rainbow represents the diffracted (or refracted) structures of an industrialized society. Inside the prism is society in transition. "The prismatic situation is neither traditional nor modern, but it contains novel elements generated by the juxtaposition of old and new social structures”. This contradicts the "escalator model" of modernization, which assumes that the prismatic characteristics would 
quickly disappear as societies are moving towards progress. To understand societies and their leadership better, one has to understand the particular features of that situation. In an attempt to better understand the art of Panay, it is important to note that the white and the refracted lights in the prismatic model hold true in a continuously developing artistic tradition in a flux. The white light represents the influences of old masters like Fabian de la Rosa, Fernando Amorsolo, and other classicists as they celebrate life's ambiance especially of the rural milieu or perhaps document significant landmarks and festivals; while the refracted light is the semblance of the modern and post-modern energies in art making with the leading lights of modernism: Victorio Edades, Carlos "Botong” Francisco, and Galo Ocampo and the foreign counterpart Constantin Brancusi, as well as the persuasions of current Filipino icons Gabriel Barredo and Charlie Co among others.

The white and refracted lights can never be divorced as both are fused in Panayanon artistic tradition. Parallel to the analogy of a transitional society where art finds its milieu, a better understanding of the development of artistic tradition cannot use the linear model which assumes the disappearance of the classic approaches among artists as a result of the morphing fusion of the early, modern, and avant-garde movements. The traditional persuasions are still used as society does not stop the demand to romanticize and document culture in a more literal yet stylized ways.

The civilization in transition has both elements shown in the traditional and modern society. Implied to this are dissensus and poly-normativism seen as those observed in the structures, lifestyles, and issues in the urban and rural contexts. In the urban setting, challenges of alienation, waste disposal, and more dehumanized existence have been observed, although varying in intensity depending on the city concerned. Challenges in the rural areas have always been on the lack of infrastructure and social services, poverty, and slow social mobility. The mixture of agricultural and industrial lifestyles also persists. Sentiments, therefore, vary as seen in Alex Ordoyo, Jose Dureza, and Edgar Gonzales in one cluster vis-à-vis Allain Hablo, Martin Genodepa, Gary Custodio, Edmar Colo, PG Zoluaga, and Angelo Duarte in another.

The art scene is another delimiting force to consider. Compared with Davao, Bacolod, and Cebu, Panayanon artists, find less political support, while their unity is less evident through the years. Rarely have institutions been diligent and philanthropic-minded in supporting the development of the artists or in documenting the local heritage as implicated by the absence of this research despite the presence of competitive visual artists who are well-respected among the cultural community. This could have been addressed for the Constitution mandates that "The State shall foster the preservation, enrichment, and dynamic evolution of a Filipino national culture based on the principle of unity in diversity in a climate of free artistic and intellectual expressions” (Article IV, section 14 and 15).

Cognizant of the Constitutional mandate, the "right to culture" based on the universal declaration of human rights by the United Nations makes the participation to visual arts a basic human right where participation should not be taken only as a luxurious option in the mindset of the typecast stinginess among the community members. On this premise, the agents of change-the policy-makers, artists, educators, cultural workers, government agencies, the private sector, and the non-government organizations- - have more reasons to give more respect and understanding for the creative forces of society.

The formalist elements of the Panay artistic tradition undeniably borrow foreign approaches such as the use of canvas in a rectangular or square presentation, impressionism, expressionism, minimalism, and use of acrylic or oil. The leading Panay artists, however, do not deny their preferences forming their identities such as the use of 
rust pigments in some of the works of Edmar Colmo, soil in Allain Hablo's, indigenous and found objects in Angelo Duarte's, coral stones drifted in beaches for Martin Genodepa, and drawing and painting combination using vinyl in Edgar Gonzales' works. Philippine art that uses the Western tradition does not lose its being Filipino according to Benesa (2009). The argument on what makes art Filipino is settled, because the artist and the culture presented are of the country. The same is true with Panay artistic tradition reflecting foreign influences in one way or another yet retaining a Panay and individual identity through the artist's creating a unique expression in the context of culture.

The backgrounds of the leading artists in Panay make one aware that eight out of nine are self-taught artists and only Gary Custodio has a fine arts course to back up his art making. Being self-taught is an advantage for it gives the artists more freedom to innovate their approaches in medium and presentation. Their expressions freely flow from the pure creative springs without the "taming" forces or perhaps delimiting standards set by academe. Without such academic training, they still manage to be at the top, even defying many who are "formally trained". The leading artists' early inclinations in childhood pushed them to pursue their artistic career with passion. They have fought well the battle for survival.

Table 1

\section{Summary of the Features of the Panayanon Artistic Tradition}

\begin{tabular}{|c|c|c|c|c|c|c|}
\hline Artists & Category & Medium(s) & $\begin{array}{l}\text { General outstanding } \\
\text { feature(s) }\end{array}$ & Style & $\begin{array}{c}\text { Notable } \\
\text { influence(s) }\end{array}$ & $\begin{array}{l}\text { Emotion(s) } \\
\text { imparted }\end{array}$ \\
\hline Edmar Colmo & Painting & $\begin{array}{l}\text { Pen and ink, oil, } \\
\text { rust pigment }\end{array}$ & $\begin{array}{l}\text { Linear strokes and medium } \\
\text { in the entire composition } \\
\text { give a fresh presentation }\end{array}$ & Surrealism & $\begin{array}{l}\text { Edvard } \\
\text { Munch, } \\
\text { Charlie Co. }\end{array}$ & $\begin{array}{l}\text { Despair, gloom, } \\
\text { pain, alienation }\end{array}$ \\
\hline Gary Custodio & Painting & Watercolor & $\begin{array}{l}\text { The use of medium in a } \\
\text { minimal presentation is } \\
\text { poetic }\end{array}$ & $\begin{array}{l}\text { Abstract } \\
\text { expressionism }\end{array}$ & \begin{tabular}{|l|} 
abstractionists, \\
Robert Morris, \\
Donald Judd \\
\end{tabular} & $\begin{array}{l}\text { Alienation, } \\
\text { insecurity }\end{array}$ \\
\hline $\begin{array}{l}\text { Angelo } \\
\text { "Jun-jun" } \\
\text { Duarte }\end{array}$ & $\begin{array}{l}\text { Wall-mounted } \\
\text { mixed media }\end{array}$ & $\begin{array}{l}\text { Recycled objects, } \\
\text { textile, oil, wood, } \\
\text { indigenous } \\
\text { materials }\end{array}$ & $\begin{array}{l}\text { Concepts are fresh and goes } \\
\text { hand in hand with the media }\end{array}$ & $\begin{array}{l}\text { Minimalism, } \\
\text { conceptualism }\end{array}$ & $\begin{array}{l}\text { Gabriel } \\
\text { Barredo }\end{array}$ & $\begin{array}{l}\text { Curiosity, } \\
\text { concern for } \\
\text { environment }\end{array}$ \\
\hline $\begin{array}{l}\text { Jose "Joe” } \\
\text { Dureza }\end{array}$ & Painting & Watercolor & $\begin{array}{l}\text { Sentiments of migrants are } \\
\text { recognized in the US and } \\
\text { locally, and they are } \\
\text { presented with refined skills }\end{array}$ & $\begin{array}{l}\text { Impressionism, } \\
\text { romanticism }\end{array}$ & \begin{tabular}{|l} 
Ancient \\
Chinese \\
paintings, \\
Winslow \\
Homer, Dong \\
Kingman
\end{tabular} & $\begin{array}{l}\text { Sentimentalism, } \\
\text { delight with } \\
\text { nature }\end{array}$ \\
\hline $\begin{array}{l}\text { Martin } \\
\text { Genodepa }\end{array}$ & $\begin{array}{l}\text { Sculpture } \\
\text { (free-standing }\end{array}$ & $\begin{array}{l}\text { Coral stone, } \\
\text { sandstone }\end{array}$ & $\begin{array}{l}\text { Expressive faces or torsos } \\
\text { in coral stone is a vanguard } \\
\text { approach }\end{array}$ & $\begin{array}{l}\text { Minimal } \\
\text { presentation of } \\
\text { figure or face }\end{array}$ & $\begin{array}{l}\text { Constantin } \\
\text { Brancusi }\end{array}$ & $\begin{array}{l}\text { Romance, } \\
\text { reservation }\end{array}$ \\
\hline $\begin{array}{l}\text { Edgar } \\
\text { Gonzales }\end{array}$ & Painting & \begin{tabular}{|l|} 
Pen and ink on \\
vinyl, watercolor, \\
acrylic
\end{tabular} & $\begin{array}{l}\text { Elements of drawing and } \\
\text { painting create a laudable } \\
\text { style to document culture }\end{array}$ & $\begin{array}{l}\text { Drawing } \\
\text { combined with } \\
\text { painting }\end{array}$ & $\begin{array}{l}\text { Fernando } \\
\text { Amorsolo, } \\
\text { modernists }\end{array}$ & $\begin{array}{l}\text { Sentimentalism, } \\
\text { concern for the } \\
\text { common }\end{array}$ \\
\hline Allain Hablo & $\begin{array}{l}\text { Wall-mounted } \\
\text { mixed media }\end{array}$ & $\begin{array}{l}\text { Automotive paint, } \\
\text { acrylic, oil, soil }\end{array}$ & $\begin{array}{l}\text { Concepts engage the } \\
\text { viewers in a unique manner }\end{array}$ & $\begin{array}{l}\text { Minimalism, } \\
\text { conceptualism }\end{array}$ & $\begin{array}{l}\text { Robert Morris, } \\
\text { Donald Judd }\end{array}$ & $\begin{array}{l}\text { Curiosity, } \\
\text { meditative } \\
\text { feeling } \\
\end{array}$ \\
\hline Alex Ordoyo & Painting & Watercolor & $\begin{array}{l}\text { His proven skills in } \\
\text { watercolor give him the } \\
\text { edge to document culture }\end{array}$ & $\begin{array}{l}\text { Impressionism, } \\
\text { expressionism, } \\
\text { romanticism }\end{array}$ & \begin{tabular}{|l} 
modernists, \\
leading \\
watercolorists \\
\end{tabular} & $\begin{array}{l}\text { Sentimentalism, } \\
\text { concern for the } \\
\text { common }\end{array}$ \\
\hline PG Zoluaga & Painting & $\begin{array}{l}\text { Acrylic, oil, } \\
\text { watercolor }\end{array}$ & $\begin{array}{l}\text { Distortions, symbolisms } \\
\text { and expressive lines } \\
\text { effectively portray the } \\
\text { message }\end{array}$ & Surrealism & $\begin{array}{l}\text { Edvard } \\
\text { Munch, } \\
\text { Charlie Co. }\end{array}$ & $\begin{array}{l}\text { Despair, gloom, } \\
\text { pain, alienation }\end{array}$ \\
\hline
\end{tabular}


A semiotic analysis of the works of the leading Panay artists reveals a diversity of themes, emotions, media, styles, influences, and outstanding features (see Table 1) which fits the earlier-mentioned prismatic model. This diversity shows that even with some contextual similarities, the works of the artists have different messages, personalities, and sources of inspiration. They can be viewed in a horizon of meaning implying a range of significations that the works accommodate yet the analyses strived to a more stable and consensual interpretations. What is common among the artists is the strength of resolve to present their true voices.

The Panay artistic tradition is not about the dominance of artistic elements, themes, emotions, media, styles, influences, and outstanding features but rather a presentation of Panay communal life, beliefs, moral virtues, and personality. In some cases, it is about man's universal desire for a continuous engagement with the elements of nature which he needs to preserve.

Where the pragmatic and materialistic values prevail in cities with less dignifying forces of modernization, many of the leading Panay artists take the role of the seer prophesying the impending doom of decline and decay or simply engage the viewers with inoffensive narratives of humankind exploiting nature. Where local heritage, festivals, and aspects of rural culture bring sentimental and light-hearted appreciation, a few of the leading artists prefer to romanticize or give tribute to them through impressionism as a natural reaction.

The leading lights of Panay visual arts are mostly avant garde of their respective media and approaches; they are adventurers sailing in a rough sea. They are mostly offshoots of the modern and post-modern movements and their works invite accolades for their scintillating excellence-like exquisite sails in the famous Paraw Regatta - that tell about self-consciousness, or consciousness of the self in the sea of assimilating identities. This self makes sense of time and space, a knowledge that plays out in the context of a marked presence. Panay artists in this study share this disposition.

\section{Conclusions}

Unique among the Panayanon artists is their individual identity reflecting the sentiments, culture, and history of the pluralistic society or the places of their temporary engagement. A collective description cannot be made as a simplistic whole entity or movement for even in the communal upbringing which has the same environment, the personalities, media, style, and subject preferences made art a complex presentation of various moods and seasons in an evolving society. The pluralistic society also yields pluralistic art. Leading artists in Panay have developed a stable visual presentation of their body of works using new innovations in media and approaches which leave an easily recognizable hallmark pointing at the creators. The visual presentations remain hinged in Panayanon culture although some deal with universal issues. They narrate descriptions of the material component of community life; market systems applying concepts of tiyanggi, pakyaw, and alsada; heritage sites such as churches; festivals such as Dinagyang, Carabao-Carroza race, and Pasungay; value orientation on relational imperatives that gives premium to kakugi, kalulo, and amuma; moral imperative that values huya; and global issues dealing with the plight of man in technologically-driven society.

The Panay artists' unbridled expression is observed to embody a fresh philosophy in art making. The works may have influences from Manila or foreign icons but the manner by which the works "re-presents" reality manifests vanguard characteristics.

In a state of a flux, Panay art has been evolving and what is common among the leading artists is the role of 
peers who challenge their achievement motivation, active participation in cultural activities or contests, non-reliance on the nurturing of the fine arts by the academe, and undaunted aggressiveness and determination of the artists to continue art making regardless of the level of community appreciation. Amid "stereotypes", the artists do not lack the credibility to earn respect in the national art scene.

As prophets and powerful princes of change like Picasso with his Guernica, Panay artists ideally occupy a respectable place in Panayanon society.

\section{References}

Barrett, T. (1994). Criticizing art: Understanding the contemporary. Mountain View, C.A.: Mayfield Publishing Company.

Benesa, L. (2009). What is Philippine about Philippine art. Retrieved from http:www.ncca.gov.ph

Bernabe-French, Z. (1995, December 7). The Martin Genodepa one-man exhibit at the UPV Art Gallery: A review. Sunstar Iloilo Daily Times.

Briones, L. (2003). Fiscal and monetary policies as constraints to development. In V. A. Bautista (Ed.), Public administration in the Philippines: A reader (pp. 554-566). Manila, Philippines: National College of Public Administration and Governance, University of the Philippines, Diliman.

Coseteng, A. (1972). Spanish churches in the Philippines. Quezon City, Manila: New Mercury Printing Press.

Defensor, E. (1992). The life and art of Vicente de San Miguel (An unpublished master’s thesis, UP Diliman, Quezon City).

Don Carlos Palanca Memorial Awards for Literature. (2000). An anthology of winning works. Manila, Philippines: Anvil Publishing, Inc..

Funtecha, H. (1995). Popular festivals in Western Visayas. Center for Western Visayas Studies, UPV, Iloilo City: MLC The New La Editorial Printing Press.

Guillermo, A. (1999, October 7). Doing sculpture in Iloilo. Today’s Weekender, No. 379, 7.

Guillermo, A. (2001). Image to meaning: Essays on Philippine art. Bellarmine Hall, Katipunan Avenue, Loyola Heights, Quezon City, Manila: Ateneo De Manila University Press.

Hernandez, E. (2009). The American and contemporary traditions in Philippine visual arts. Retrieved from http:www.ncca.gov.ph Kintanar, T. (2004). Self-portrait 2: 14 Filipino women artists. Quezon City: Ateneo University Press.

Larawan, L. (2008). The Ilonggo artistic tradition in the lives and works of ten selected artists. Jaro, Iloilo City: University Research Center, Central Philippine University.

Living in Manila (Editorial). (2010, September 30). The Philippine Star.

Querubin, N. (2004). The potter's memoir: The clay found me when my heart cried to create (Unpublished manuscript).

Querubin, N. (2005). Patterned and inscribed: The art of Nelfa Querubin. UP Jorge B. Vargas Museum \& Filipina Research Center, Roxas Avenue, University of the Philippines, Diliman, Quezon City: Nelfa Querubin-Tompkins.

Reyes, C. (Art critic). (1999). Young painter's annual. [Winner’s Exhibit]. Manila, Philippines.

The Holy Bible, new international version. (1984). Manila, Philippines: Image Builders Services and Publishing Foundation, Inc.. 